\title{
New records for species of Theope (Lepidoptera, Riodinidae) for the state of Pernambuco and northeastern Brazil, with notes on their natural history
}

\author{
Carlos Eduardo Beserra Nobre ${ }^{1} \&$ Clemens Schlindwein ${ }^{1}$
}

1'Departamento de Botânica, Universidade Federal de Pernambuco, 50670-901 Recife-PE, Brasil. cebnobre@yahoo.com.br

\begin{abstract}
New records for species of Theope (Lepidoptera, Riodinidae) for the state of Pernambuco and northeastern Brazil, with notes on their natural history. Five new records for the state of Pernambuco and one new record for NE-Brazil are reported in this paper for the genus Theope. Relationship between ants and T. terambus was observed for the first time which also consists on the first ever recorded myrmecophilous interaction between Pheidole ants and a Theope immature. Schoepfia guianensis is reported as a probable hostplant for T. terambus. Illustrations of seven species of Theope which occur in the northeastern Atlantic Rainforest are provided.
\end{abstract}

KEYWORDS. Myrmecophily; Nymphidiini; Pernambuco endemism center.

RESUMO. Novas ocorrências do gênero Theope (Lepidoptera, Riodinidae) para Pernambuco e Nordeste brasileiro e comentários de sua história natural. São registradas cinco novas ocorrências do gênero Theope para Pernambuco e uma nova ocorrência para o Nordeste do Brasil. É relatada pela primeira vez relação mirmecófila para T. terambus, assim como uma relação entre um imaturo de Theope e formigas do gênero Pheidole. Schoepfia guianensis é relatada como provável planta hospedeira de T. terambus. São fornecidas ilustrações para as sete espécies de Theope registradas nesse estudo.

PALAVRAS-CHAVE. Centro de endemismo Pernambuco; mirmecofilia; Nymphidiini.

Theope Doubleday, 1847 is the largest myrmecophilous genus in the butterfly family Riodinidae with 80 species. Since the genus was reviewed by Hall (1999), 11 new species were described (Gallard 2002, 2006; Hall 2008; Jauffret \& Jauffret 2009; Brévignon \& Gallard 2009) and others are likely to be discovered, especially in the Amazon basin (Hall 2008). In general, its species are small sized, with abundant iridescent blue scales on the dorsal surface and brown, gray or white ventrally. Characteristically, the butterflies of this genus land with their wings closed and the males perch in hilltops and ridge tops (DeVries 1997; Hall 1999).

As part of the myrmecophilous tribe Nymphidiini, Theope caterpillars have been associated with Dolichoderinae ants, notably those of the genus Azteca (Hall 1999). Although it has never been demonstrated the benefits of myrmecophily in Theope, the presence of tending ants supposedly protect its caterpillars against natural enemies, or for appeasement, in exchange for nutritious secretions as it was observed for other Lycaenidae and Riodinidae species (see Malicky 1970; DeVries 1991). The genus is exclusively Neotropical and typical of wet forest habitats. Because of their generally low abundance, inconspicuous behavior and small size, Theope species are often overlooked in surveys and poorly represented in collections and museums.

Seven Theope species are listed for the Atlantic Rainforest of Northeastern Brazil: six in the state of Paraíba (Kesselring \& Ebert 1982; Hall 1999) and two in the state of Pernambuco (Hall 1999). This coastal rainforest forms the Pernambuco endemism center (sensu Silva \& Casteleti 2003), whose species richness still remains much underestimated (Tabarelli et al. 2006). The forest coverage of this biogeographic Region is currently scattered in very small and disturbed remnants due to cut down of rainforest and sugar cane plantations (Silva \& Tabarelli 2000).

Theope individuals were sampled during four to six days per month, from April/2007 to March/2008, as part of a broader butterfly inventory that comprised approximately 300 net-sampling hours. The time of capture and approximate height of flight were registered for every collected specimen. Also, special attention was given to females fluttering about plants ("approaching"), as an indicative of possible ovipositing behavior, as described by Pierce \& Elgar (1985).

The survey took place along the edges and understorey trails (4:1 sampling hours) of Atlantic Rainforest remnants located at the Usina São José S/A (741'4.09"-754'41.6”S and $\left.34^{\circ} 05^{\prime} 17.6-35^{\circ} 05^{\prime} 07.2^{\prime \prime} \mathrm{W}\right)$, a sugarcane industry situated in the municipality of Igarassu, northern Pernambuco, Brazil. The local rainfall exhibits a rainy season from January to August and a dry season from September to December (Schessl et al. 2008). 

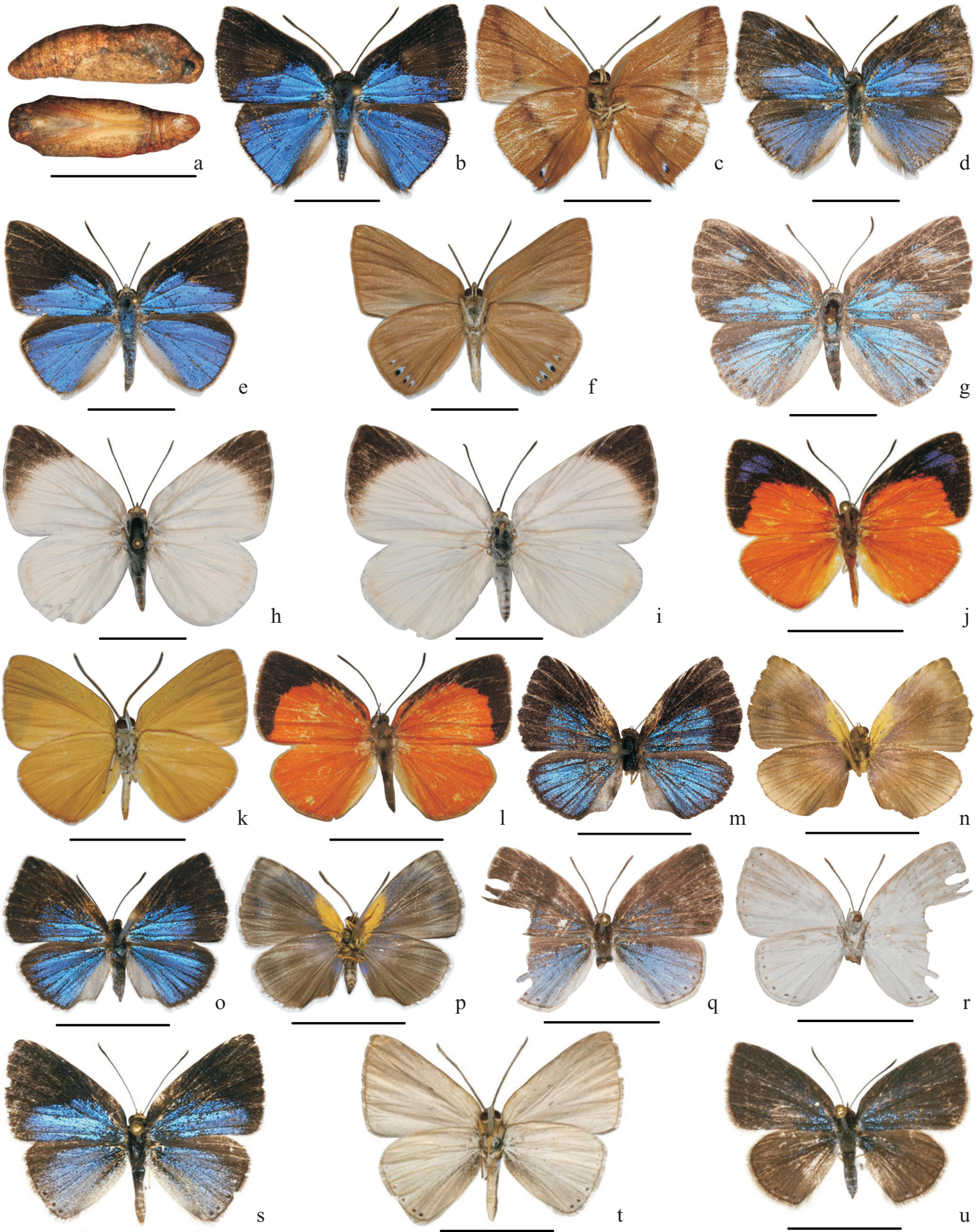

Fig. 1. Theope species sampled in Igarassu, northern Pernambuco, Brazil: T. terambus - (a) pupae in lateral and ventral view, (b) male, D (c) male, V (d) female, D; T. virgilius - (e) male, D (f) male, V (g) female, D; T. pierioides - (h) male, D (i) female, D; T. eudocia - (j) male, D (k) male, V (1) female, D; T. thestias - (m) male, D (n) male, V (o) female, D (p) female, V; T. leucanthe - (q) female, D (r) female, V; T. foliorum - (s) male, D (t) male, V (u) female, D. $\mathrm{D}=$ dorsal view; $\mathrm{V}=$ ventral view. Scale bar $=1 \mathrm{~cm}$. 
During one year of sampling, we have collected 71 individuals of seven Theope species (Table I, Fig. 1). Five species are new records for the state of Pernambuco (T. eudocia, T. foliorum, T. terambus, $T$. thestias and T. virgilius) and oneT. thestias - is a new record for the Northeastern region of Brazil. The closest area to Pernambuco in which this species occurs is in the municipality of Leopoldina, Minas Gerais, in Southeastern Brazil (Hall 1999), about $2000 \mathrm{~km}$ southwest of Igarassu.

The occurrence of Theope individuals was low throughout the sampling year and two seasonal peaks were verified: the first and highest on the wet season, from March to June and a discrete one on the dry season, from October to December (Fig. 2). The most temporally and spatially abundant species was T. eudocia, a common and widespread species, usually associated to secondary and degraded forest habitats (Hall 1999). These are common traits to most of the species found in this study (Hall 1999). All species were sampled in forest edges with the exception of T. terambus, which was also sampled in the forest understorey (Table I).

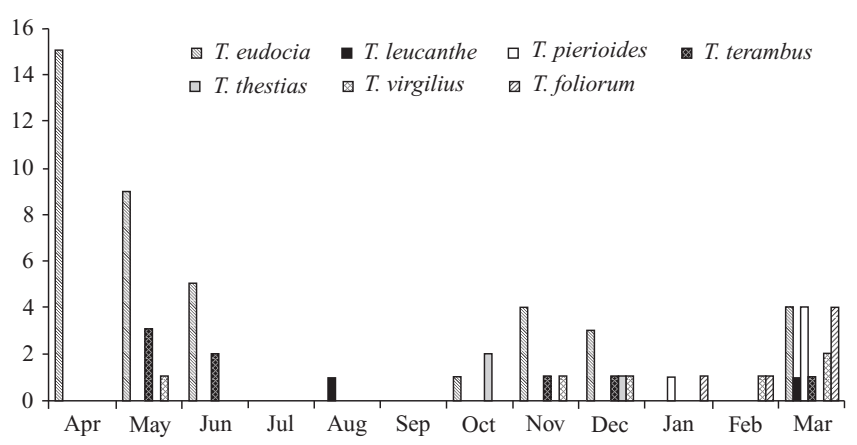

Figure 2. Occurrence of Theope species from April/2007 to March/2008 in Igarassu, northern Pernambuco, Brazil.

Hall (1999) reported a female-biased sex ratio of 6:1 for two species of Theope (T. decorata and T. guillaumei). In the present study, there was no strong sex ratio bias but the proportion of females was slightly higher in some uncommon species (Table I).
The species of the "foliorum group" (T. foliorum and $T$. leucanthe, sensu Hall 1999), smaller and more fragile, were found flying in lower heights, whereas the larger and more powerful flyers ( $T$. virgilius, $T$. terambus, T. pierioides) flew higher from the ground (Table I).

A female of $T$. terambus was found in the forest understorey, approaching the leaves of an individual of Schoepfia guianensis Aubl. (Olacaeae) in a typical ovipositing behavior. After investigating the plant, a light to dark brown-mottled pupa of T. terambus (Fig. 1a) was found hidden in a foraging trail constructed by a species of Pheidole ant. It was attached to a tree branch by the cremaster, with its dorsal surface lying against the foraging trail wall. Pupation inside an ant built structure (carton) was already documented for T. lycaenina by Hall (1999). This behavior may comprise a complementary strategy to avoid natural enemies, analogue to shelter building by several Lepidoptera species (see Kaminski et al. 2009), including other Theope (Hall 1999; Kaminski 2008).

After eight days, a male adult of T. terambus emerged (Fig. 1b-c). The plant individual was revisited on several other occasions to find additional immatures but none was found and the ants seemed to have abandoned their local foraging trail.

To date, there have been reports of Theope larvae associated with ants of the genera Azteca, Solenopsis and Dolichoderus (Harvey 1987; DeVries et al. 1992; DeVries 1997). Although we have not found T. terambus larvae associated to the ants, this is the first record of a relationship between ants and an immature stage (pupa) of this species. In Theope, myrmecophily in the pupal stage was already observed, for T. thestias and T. pierioides (Kaminski, pers. comm.).

Pheidole ants had already been documented in association with riodinids of the genera Thisbe, Protonymphidia, Setabis, Nymphidium and Eurybia (DeVries 1991; DeVries et al. 1992). This is the first record of an association between this ant genus and a species of Theope.

The utilization of Schoepfia guianensis as foodplant by T. terambus larvae needs to be confirmed, consisting on the first record of an Olacaceae species as hostplant for the genus Theope (Beccaloni et al. 2008). We believe it is a plausible

Table I. Butterfly species of the genus Theope sampled in Atlantic forest fragments of Igarassu, Pernambuco.

\begin{tabular}{|c|c|c|c|c|c|}
\hline \multirow{2}{*}{ Theope species } & \multicolumn{2}{|c|}{ Number of individuals } & \multirow{2}{*}{ Habitat } & \multirow{2}{*}{$\begin{array}{l}\text { Height of flight } \\
\text { (m) }\end{array}$} & \multirow{2}{*}{$\begin{array}{c}\text { Time of occurrence } \\
\text { (h) }\end{array}$} \\
\hline & Male & Female & & & \\
\hline T. eudocia Westwood, 1851 & 22 & 19 & Forest edge & $1,0-5,0$ & $09: 30-14: 50$ \\
\hline T. foliorum H.W. Bates, 1868 & 2 & 4 & Forest edge & $0,5-1,5$ & $11: 00-12: 20$ \\
\hline T. leucanthe H.W. Bates, 1868 & 0 & 2 & Forest edge & $0,5-1,5$ & $12: 00-14: 15$ \\
\hline T. pierioides C. felder \& R. Felder, 1865 & 2 & 3 & Forest edge & Above 3 & $11: 30-14: 00$ \\
\hline T. terambus (Godart, [1824]) & 3 & 5 & Forest edge/Understorey & $2,0-4,0$ & $10: 00-13: 20$ \\
\hline T. thestias Hewitson, 1860 & 1 & 2 & Forest edge & $1,5-3,0$ & $10: 30-11: 30$ \\
\hline T. virgilius (Fabricius, 1793) & 4 & 2 & Forest edge & $2,5-4,0$ & $11: 00-13: 20$ \\
\hline
\end{tabular}


hypothesis, because of two significant evidences: a) the presence of a symbiotic ant species on the plant, which could have influenced the female to oviposit in an unusual plant species (Pierce 1984; Pierce \& Elgar 1985), and b) the pupation on $S$. guianensis host plant, since this behavior is already known for other Theope species (Kaminski, pers. comm.).

These findings illustrate the current situation on the state of knowledge of many animal groups of Northeastern Brazil, especially those which requires more specific and methodic surveys. The rapid impoverishment taking place at local forest fragments (Silva \& Tabarelli 2000; Lopes et al. 2009) demands intensified research effort, in order to further elucidate the poorly understood biodiversity of this region.

\section{ACKNOWLEDGEMENTS}

We thank Frederico Cavalcanti de Petribú Vilaça and Roberto Siqueira of the Usina São José S/A for the permission to execute the fieldwork, Artur Maia and Poliana Ojima for field assistance, Msc. Anderson Alves-Araújo and E. Pessoa for the identification of the plant and Msc. Juliana Gomes for the identification of the ants. We specially thank Dr. Márlon Paluch for his guidance during the dissections of butterfly genitalia and Lucas A. Kaminski for bibliographic handouts and discussion on immatures. This work is part of the BrazilianGerman scientific cooperation project "Stability of rainforest remnants in NE Brazilian state of Pernambuco" funded by CNPq (69014701-5) and BMBF (01-LB-0203).

\section{REFERENCES}

Beccaloni, G. W.; A. L. Viloria; S. K. Hall \& G. S. Robinson. 2008. Catalogue of the hostplants of the neotropical butterflies/Catálogo de las Plantas Huésped de las Mariposas Neotropicales. $\mathrm{m} 3 \mathrm{~m}$ Monografías Tercer Milenio, Volume 8. Zaragoza, Sociedad Entomológica Aragonesa (SEA), 536 p.

Brévignon, C. \& J.-Y. Gallard. 2009. Description de deux nouvelle espèces du genre Theope provenant de Guyane Française (Lepidoptera Riodinidae) Lambillionea 109: 501-504.

DeVries, P. J. 1991. Mutualism between Thisbe irenea butterflies and ants, and the role of ant ecology in the evolution of larval-ant associations. Biological Journal of the Linnean Society 43: 179-195.

DeVries, P. J. 1997. The Butterflies of Costa Rica and their Natural History, Vol. II: Riodinidae. New Jersey, Princeton University Press, 288 p.

DeVries, P. J.; I. A. Chacón \& D. Murray. 1992. Towards a better understanding of host use and biodiversity in riodinid butterflies (Lepidoptera). Journal of Research on the Lepidoptera 31: 103-126.

Jauffret, P. \& J. C. Jauffret. 2009. Description de quatre espèces nouvelles de Theope Doubleday, 1847 originaires du Bresil et du Paraguay, Description de la femelle de T. minalba Gallard, 2006 (Lepidoptera:
Riodinidae: Nymphidiini). Lambillionea 109: 155-164.

Gallard, J.-Y. 2002. Description d'une nouvelle espece de Theope Amazonien et de sa sousespece Guyanaise (Lepidoptera: Riodinidae, Nymphidiini). Lambillionea 102: 463-467.

Gallard, J.-Y. 2006. Deux nouveaux Riodinidae de Guyane Francaise (Lepidoptera). Lambillionea 106: 26-28.

Hall, J. P. 1999. A revision of the genus Theope (Lepidoptera: Riodinidae) - Its systematics and biology. Gainesville, Scientific Publishers, viii+128 p.

Hall, J. P. 2002. Phylogeny of the riodinid butterfly subtribe Theopeina (Lepidoptera: Riodinidae: Nymphidiini). Systematic Entomology 27: 139-167.

Hall, J. P. 2008. Theope revisited: a synopsis of new discoveries, with the description of three new species (Lepidoptera: Riodinidae: Nymphidiini). Proceedings of the Entomological Society of Washington 110: 144158.

Harvey, D. J. 1987. The Higher Classification of the Riodinidae (Lepidoptera). Austin, Phd Thesis, University of Texas, $216 \mathrm{p}$.

Kaminski, L. A. 2008. Immature stages of Caria plutargus (Lepidoptera: Riodinidae), with discussion on the behavioral and morphological defensive traits in nonmyrmecophilous riodinid butterflies. Annals of the Entomological Society of America 101: 906-914.

Kaminski, L. A., Sendoya, S. F., Freitas, A. V. L. \& Oliveira, P. S. 2009. Ecologia comportamental na interface formiga-planta-herbívoro: interações entre formigas e lepidópteros. Oecologia Brasiliensis 13: 27-44.

Kesselring, J. \& H. Ebert. 1982. Relação das borboletas encontradas na "mata do buraquinho", João Pessoa, estado da Paraíba, Brasil. Revista Nordestina de Biologia 2: 105-118.

Lopes, A. V; L. C. Girão; B. A. Santos; C. A. Peres \& M. Tabarelli. 2009. Long-term erosion of tree reproductive trait diversity in edge-dominated Atlantic forest fragments. Biological Conservation 142: 1154-1165.

Malicky, H. 1979. New aspects on the association between lycaenid larvae (Lycaenidae) and ants (Formicidae, Hymenoptera). Journal of the Lepidopterists' Society 24: 190-202.

Pierce, N. E. 1984. Amplified species diversity: a case study of an australian lycaenid butterfly and its attendant ants, p. 197-200. In: R. I. WaneWright \& P. R. Ackery (Eds.). The biology of butterflies. Symposium of the Royal Entomological Society of London Number 11. London, Academic Press, $429 \mathrm{p}$.

Pierce, N. E. \& M. A. Elgar. 1985. The influence of ants on host plant selection by Jalmenus evagoras, a myrmecophilous lycaenid butterfly. Behavior Ecology and Sociobiology 16: 209-222.

Schessl, M.; W. L. Silva, \& G. Gottsberger. 2008. Effects of fragmentation on forest structure and litter dynamics in Atlantic rainforest in Pernambuco, Brazil. Flora 203: 215-228.

Silva, J. M. C. \& C. H. M. Casteleti. 2003. Status of the Biodiversity of the Atlantic Forest of Brazil, p. 43-59. In: C. Galindo-Leal \& I. G. Câmara (Eds.). The Atlantic Forest of South America: Biodiversity Status, Threats, and Outlook. Washington, CABS \& Island Press, 488 p.

Silva, J. M. C. \& M. Taberelli. 2000. Tree species impoverishment and the future flora of the Atlantic forest in northeast Brazil. Nature 404: 7274.

Tabarelli, M.; J. A. S. Filho \& A. M. M. Santos. 2006. A floresta Atlântica ao norte do Rio São Francisco, p. 25-37. In: K. C. Porto; J. S. AlmeidaCortez \& M. Tabarelli. (Orgs.) Diversidade biológica e conservação da floresta Atlântica ao norte do Rio São Francisco. Brasília, Ministério do Meio Ambiente, 363 p. 